\title{
The Efficacy of Various Bacterial Organisms for Biocontrol of Fusarium Root Rot of Olive in Tunisia
}

\author{
Amira Bouzoumita ${ }^{1 *}$, Mounira Metoui ${ }^{1}$, Monia Jemni², Nadia Kabaeir ${ }^{1}$, \\ Khaled Belhouchette ${ }^{1}$, Ali Ferchichi ${ }^{3}$ \\ ${ }^{1}$ Arid Lands and Oases Cropping Laboratory, The Arid Regions Institute of Medenine, Tunisia \\ ${ }^{2}$ Regional Research Center in Oasis Agriculture of Degache, Tozeur, Tunisia \\ ${ }^{3}$ Rural Laboratory, National Institute of Agronomic of Tunisia
}

Received: 8 December 2017

Accepted: 16 April 2018

\begin{abstract}
Biocontrol research has the potential for managing Fusarium root rot of olive. This latter is treated by the use of isolated bacteria from the soil of olive orchards of Tunisia: Bacillus Licheniformis and Enterobacter Colcae. It was demonstrated that these two bacteria are effective against Fusarium solani and oxysporum. In an initial screening, two efficacy bacteria were isolated with a reduction of disease incidence. In vitro, both biocontrol agents were highly tolerant to the carbendazime fungicide commonly used to control Fusarium diseases. It was observed that carbendazime reduced disease symptoms at a concentration of $>50 \mu \mathrm{g} \mathrm{mL}^{-1}$. The combination of the bacterial isolates and carbendazime gave a significant $(P \leq 0,05)$ control of the disease when plants were artificially inoculated with the pathogen. The application of carbendazime at a low concentration $\left(10 \mu \mathrm{g} \mathrm{mL}^{-1}\right)$ in combination with Bacillus B4 reduced disease symptoms by $51 \%$, compared with a reduction of $46 \%$ obtained with the bacterium alone and no control with the chemical treatment alone. A combination of Bacillus with fungicide increased the application rate of $10 \mu \mathrm{g} \mathrm{m}^{-1}$ carbendazime and significantly reduced disease symptoms by $74 \%$ compared to $34 \%$ with carbendazime treatment alone and, respectively, a combination fungicide and Enterobacter E4 increased the disease by $84 \%$ compared with $55 \%$ for bacteria alone. In this experiment, the integrated treatment also slightly outperformed the application of $100 \mu \mathrm{g} \mathrm{mL}^{-1}$ bacteria Bacillus and Enterobcater applied, and without fungicide also provided good disease control.
\end{abstract}

Keywords: Fusarium root rot; bacterial biocontrol; olive 


\section{Introduction}

Olive (Olea europaea L) is considered one of the most important economic fruit crops in the world as well as in Tunisia. It is grown extensively in the Mediterranean Basin [1]. Recently in Tunisia, a decline of tree production has been due to a fungal complex that causes various types of symptoms like yellowing, defoliation, dwarfism, deterioration and drying of the seedlings. [2] has observed this phenomenon in different cultivation areas in Tunisia. A dieback of olive trees has occurred in olive orchards, where it has caused severe devastation. Fusarium root rot of olive trees, caused by Fusarium solani ssp and oxysporum, is one of the most serious diseases attacking olive trees (Olea europaea) in Tunisia [3]. Olive trees and transplants are subject to attack by several soil-borne pathogens that cause severe damage in nurseries and orchards. Root rot of olive is primarily caused by several pathogens such as Fusarium oxysporum, F. solani, and other fungi [4-6]. These pathogens are capable of surviving in the soil in the absence of their host plants, and might become destructive under favorable conditions. Fusarium is able to survive in the soil for years and to infect a wide range of hosts [7, 8]. In fact, the control of this soil-born fungus remains limited. The propagation in tissues of dead plants, including olive leaves, limits the efficacy of chemical treatments against this fungus, whose pathogen the inoculums surviving in soil in microcorporates [7] and infects the vascularization of plants. It is difficult to reach these parts with fungicides. Chemical control using many antifungal products sometimes provided good control in the field. Taking advantage of the thermosensitivity of Fusarium, soil solarization treatment and thermal treatments have been applied to control this pathogen. This method successfully inhibited the pathogen growth in vitro and vivo and enhanced natural resistance against plant diseases [9]. Among other solutions against this disease, it is noted that grafting onto resistant varieties [10] and useful soil microorganisms as mentioned by El-Morsi et al. (2009), Sivasakthi et al. (2014), and Kamble et al. (2012) [5, 11, 12].

Dissemination of the pathogen is very difficult to prevent because Fusarium can survive in infected soil and olive as mycelium, chladmydospores, macroconidia and microconidia. In addition, the pathogen may also be carried on symptomless or mildly affected transplants. Many different control measures were suggested when the decline of olive trees caused by Fusarium was first identified in Tunisia. The initial control efforts were made to limit disease spread by sanitation and quarantine procedures, but these proved unsuccessful.

Although carbendazim-based fungicides can afford a good level of disease suppression, the relatively poor efficacy of chemical control and the lack of resistance in some commercially important olive cultivars have focused attention on the feasibility of biological control of the pathogen $[13,14]$. This biological control of plant pathogens using antagonistic bacterial strains is playing an important role in the management of plant diseases [15]. Bacillus and Enterobacter are considered interesting classes of biocontrol bacteria that are used frequently against various plant diseases [16]. Previously, B. subtilis had high antibacterial activity in vitro. The use of biocontrol agents in conjunction with fungicides may therefore be a valuable complementary strategy for control of dieback of olive. An additional benefit of using such an integrated approach is that lower doses of fungicides could be used, with associated benefits of reduced residues and environmental impact.

The objective of this research is to evaluate the efficiency in vitro and in situ of some bacterial organism for biocontrol on the development of the fungi agents responsible for the deterioration of olive trees in the area of Tunisia by assessing root rot of olive caused by Fusarium occurrence and by evaluating the effect of antifungal activity of bacteria, namely: Bacillus and Enterobacter as treatments on controlling this disease combined or not with low doses of the fungicide carbendazim. This approach constitutes a promising strategy for disease control insufficiently explored yet.

\section{Experimental}

\section{Microorganisms and Inoculum Production}

Cultures of Fusarium were isolated from affected olive trees. Potential biological control bacterial agents were originally isolated in a rhizosphere of tree to select antagonists of Fusarium root rot of olive. The isolated bacteria that showed activity against $F$. oxysporum $s p$. were used in this study. Cultures were maintained on slants of potato dextrose agar (PDA). Along the experiment, Enterobacter and Bacillus were grown respectively on King B Agar (KBA) supplemented with $100 \mathrm{ppm}$ rifampicin (KBA $+100 \mathrm{ppm}$ of rifampicin plates) and incubated for $24 \mathrm{~h}$ at $26^{\circ} \mathrm{C}$ and on $\mathrm{KBA}$ at $26-28^{\circ} \mathrm{C}$ for $24 \mathrm{~h}$. Bacterial suspensions were prepared in $10 \mathrm{mM}$ at $4^{\circ} \mathrm{C}$ for fungi and bacteria. Bacterial isolates were maintained on nutrient agar (NA) (CM 3, Oxoid) slants at $4^{\circ} \mathrm{C}$ and also as frozen cultures in $15 \%$ glycerol at $-20^{\circ} \mathrm{C}$. Pathogenicity of Fusarium was maintained by inoculation and reisolation from infected plants approximately every 6 months.

\section{Production of Fusarium Conidial Suspensions}

Microconidia of Fusarium were obtained by flooding 7-day-old cultures grown on PDA in Petri dishes at $25^{\circ} \mathrm{C}$ with $10 \mathrm{~mL}$ of sterile distilled water (SDW). Conidia were dislodged by scraping the surface of the agar culture with a sterile glass rod. The resulting slurry was filtered through four layers of sterile muslin to remove mycelial debris. The filtrate was collected and the spores washed twice with SDW, following centrifugation at $1000 \mathrm{~g}$ for $5 \mathrm{~min}$. The concentration of microconidia 
was estimated using a haemocytometer and adjusted to the required concentration by dilution with SDW.

\section{Production of Bacterial Suspensions}

To prepare the bacterial suspensions (Bacillus and Enterobacter), slant cultures were streaked with the bacterium and incubated for $24 \mathrm{~h}$ at $26^{\circ} \mathrm{C}$. After that, the slant cultures were flooded with $10 \mathrm{~mL} \mathrm{SDW}$ and the bacteria were scraped from the agar surface with a sterile plastic loop. The suspensions were made homogeneous by agitation using a vortex mixer. $100 \mu \mathrm{L}$ of these bacterial inoculums were inoculated in flasks of $250 \mathrm{~mL}$ containing $50 \mathrm{~mL}$ of yeast peptone glucose (YPG) liquid medium (yeast extract $5 \mathrm{~g}$, bacteriological peptone $5 \mathrm{~g}$, glucose $20 \mathrm{~g} \mathrm{~L}^{-1}, \mathrm{pH} 6.8$ ), and incubated at $26^{\circ} \mathrm{C}$ and at $250 \mathrm{rpm}$ in an incubator shaker.

\section{In vivo Screening for Biological Control Activity}

In the primary in vivo screen, 90 bacterial isolates and 50 isolates of Fusarium solani and oxysporum were used. They were germinated in plastic plug trays ( $9 \mathrm{~cm}$ diameter). Seedlings were raised in a controlled environment room maintained at $25^{\circ} \mathrm{C}$ during the day and $17^{\circ} \mathrm{C}$ during the night, and with a photoperiod of $16 \mathrm{~h}$. The illumination was provided by banks of eight 400 W Osram high-intensity HQIT lamps (Osram Ltd, UK) and eight $150 \mathrm{~W}$ tungsten bulbs to give an average light intensity of $280 \mu \mathrm{mol} \mathrm{m}{ }^{-2} \mathrm{~s}^{-1}$ PAR.

Nine days after sowing, $5 \mathrm{~mL}$ of suspensions of potential antagonists were inoculated at the base of the stem of seedlings in the compost. After $24 \mathrm{~h}$ of incubation, the seedlings were similarly treated with $5 \mathrm{~mL}$ of conidial suspension at a concentration of spores of about $5 \times 10^{6} \mathrm{~mL}^{-1}$. Plants were watered every day and the wilting or the dead seedlings were recorded. Final disease assessments were made visually three months after inoculation using the numerical severity key based on chlorosis, necrosis and wilting of foliage as described by Bacon et al. (2002) [18]. Twenty-five replicate plants were used to screen each antagonist tested. Trays were rotated every 2 days to avoid position and edge effects. Screening was divided into batches of 20 isolates in order to comply with growth room capacity. As disease severity varied slightly between uninoculated controls in sequential experiments, results are presented as percentage disease reduction (DR) based on severity ratings described above, and calculated using the following equation:

$$
D R=\left(1-\frac{D T}{D C}\right) \times 100
$$

...where:

DC: the disease percentages in control DT: the disease percentages in test treatments
Isolates that have the ability to reduce disease development by $\geq 40 \%$ were chosen for a secondary screen. This second screen was performed as described above, but the inoculum was applied at an increased concentration of $10^{6}$ conidia $\mathrm{mL}^{-1}$ to increase disease pressure and hence the rigour of the selection procedure. These experiments again comprised 25 replicate plants per antagonist and were repeated three times. Standard errors were derived from pooled data from the three replicated trials.

\section{Fungicide Sensitivity of Fusarium on Amended PDA Plates}

The benzimidazole (MBC) fungicide was used in this experiment because of it efficacy in controlling Fusarium spp. [17, 18]. A series of fungicide dilutions (in $\mu \mathrm{g} \mathrm{mL}^{-1}$ active ingredient) were prepared from a $100 \mu \mathrm{g} \mathrm{mL}^{-1}$ stock solution. The fungicides were added into autoclaved PDA to give final concentrations of the active ingredient of $0.1,0.3,0.5,0.7$ and $0.9 \mu \mathrm{g} \mathrm{mL} \mathrm{m}^{-1}$. Approximately $15 \mathrm{~mL}$ of amended agar per $9 \mathrm{~cm}$ Petri dish was centrally inoculated with a $5 \mathrm{~mm}$ mycelial agar plug and incubated at $25^{\circ} \mathrm{C}$. Mean diameter of mycelial colonies were measured from day 2 until day 7 from five replicate plates for each treatment.

\section{In vitro Compatibility of Bacillus (B) and Enterobacter (E) with Carbendazim}

Sterilized YPG liquid media was amended with carbendazim diluted in SDW. Stock solutions of fungicides were added to YPG to make a volume of $50 \mathrm{~mL}$ at concentrations of 10,50 and $100 \mu \mathrm{g} \mathrm{mL}-1$. The media were inoculated with $100 \mu \mathrm{L}$ of bacterial inoculum prepared as described above, sampled every $24 \mathrm{~h}$ until $72 \mathrm{~h}$, and numbers of colony forming units were determined after serial dilution. The experiment was replicated three times.

\section{Efficacy of Biocontrol Agents in Combination with Reduced Fungicide Application Rates}

Nine days after sowing, the compost was drenched at the base of the stem olive seedlings (chemlali) with $1 \mathrm{~mL}$ carbendazim, alone or in combination with an antagonist. The fungicide was applied alone at concentrations of 1,3 and $5 \mu \mathrm{g} \mathrm{mL} \mathrm{mL}^{-1}$, or in combination with $B 1$ or at the lowest concentration only. A second experiment used fungicide concentrations of 10,50 and $100 \mu \mathrm{g} \mathrm{mL} \mathrm{mL}^{-1}$ and the bacteria were tested in combination with $10 \mu \mathrm{g} \mathrm{mL^{-1 }}$ fungicide. After $24 \mathrm{~h}$, the seedlings were drenched with $5 \mathrm{~mL}$ of Fusarium conidial suspension at $5 \times 10^{6} \mathrm{~mL}^{-1}$ of spores. The plants were watered daily and the wilted or the dead seedlings were recorded whenever seen. The experiments were repeated three times, with 25 seedlings in each treatment. 


\section{Results}

\section{In vivo Screening}

The 42 isolates used were initially selected from a population of 90 by in vitro screening for antagonism to PDA. The isolates which gave an inhibitory zone $\geq 10 \mathrm{~mm}$ between the Fusarium colonies after $96 \mathrm{~h}$ of incubation were chosen. 4 bacteria Enterobacter and 4 Bacillus gave a disease reduction greater than $\geq 20 \%$ in the primary screening, and they were selected for testing at a higher pathogen inoculum pressure $\left(10^{6}\right.$ conidia $\left.\mathrm{mL}^{-1}\right)$. Fig. 1 illustrates the disease reduction achieved by inoculation with the eight most effective bacteria when tested under the more stringent conditions. In this secondary screen, only two bacterial isolates reduce disease by $\geq 40$. Testing was able to provide adequate disease control under the higher disease pressure. The two most efficacious bacterial isolates reduced disease by $46 \%$ for Bacillus B4 and by $51 \%$ for Enterobacter E4, as subsequently identified by the Spanish National Research Council (CSIC). As these bacteria were more effective than the tested ones and they were also better at reducing vascular browning of roots, they were selected for further work on integration with the Carbendazim fungicide (Fig. 1).

The effect of different concentrations of the carbendazim fungicide $\left(\mu \mathrm{g} \mathrm{mL}^{-1}\right)$ on the growth of Fusarium oxysporum f. sp. in fungicide-amended potato dextrose agar and the variation between growths of four replicates was minimal and standard errors of the mean are not shown.

When Bacillus Licheniformis and Enterobacter Cloacae were grown in liquid culture with different concentrations of carbendazim ranging from 0 to $100 \mu \mathrm{g} \mathrm{mL} \mathrm{m}^{-1}$ to test the compatibility of these bacteria with carbendazim, the growth of both species did not differ from the control treatments. Colony numbers of $B 4$ were slightly reduced at the highest fungicide concentration, although the difference was not significant. At all concentrations tested, the growth of $B 4$ was unaffected. By $48 \mathrm{~h}$ after inoculation, E4 existed almost entirely as vegetative cells, but by $72 \mathrm{~h}$ approximately $10 \%$ of cells contained endospores. These

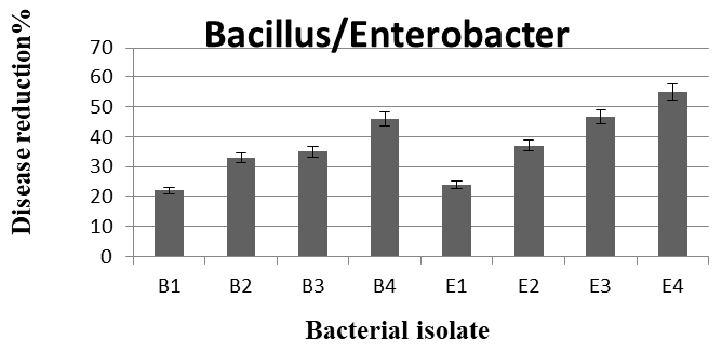

Fig. 1. Final screen of potential bacterial biocontrol isolates at high inoculum level of $10^{6}$ conidia per plant of Fusarium oxysporum f. sp.

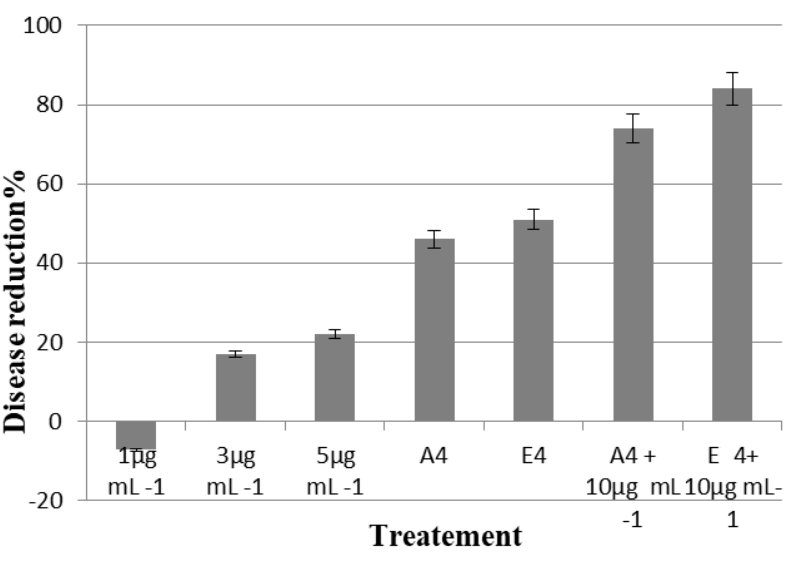

Fig. 2. Efficacy of $B 4$ and $E 4$ or carbendazim alone (1-5 $\left.\mathrm{g} \mathrm{mL}^{-1}\right)$, and carbendazim $\left(1 \mathrm{~g} \mathrm{~mL}^{-1}\right)$ combined with the biocontrol agents against Fusarium root rot.

results suggest strongly that growth of both bacterial isolates was not affected by carbendazim.

When the two biocontrol agents carbendazim alone and combinations of the bacteria with $1 \mu \mathrm{g} \mathrm{mL} \mathrm{m}^{-1}$ fungicide were evaluated, it was observed that carbendazim alone at up to $5 \mu \mathrm{g} \mathrm{mL} \mathrm{mL}^{-1}$ was not sufficiently effective (Fig. 2). Although the application of 3 or $5 \mu \mathrm{g} \mathrm{mL} \mathrm{m}^{-1}$ carbendazim significantly $(P \leq 0,05)$ reduced disease, comparative levels remained high. The combination of carbendazim with Bacillus B4 resulted a significantly greater disease reduction than B4 alone. In addition, the effect of $E 4$ was increased to $51 \%$ by the addition of the fungicide at a concentration of $10 \mu \mathrm{g}$ $\mathrm{mL}^{-1}$. However, the level of control of root rot Fusarium given by this concentration of fungicide, with or without the biocontrol agents, or by the antagonists alone, was inadequate. This may reflect the atypically high pathogenicity of Fusarium in this experiment (Fig. 2).

At the higher concentrations of fungicide (10, 50 and $100 \mu \mathrm{g} \mathrm{mL} L^{-1}$, the disease was significantly $(P \leq 0,01)$ suppressed (Fig. 3$)$. The highest concentration $\left(100 \mu \mathrm{g} \mathrm{mL}^{-1}\right)$ reduced the disease index by more than $34 \%$. Both of the bacteria tested, alone or in combination

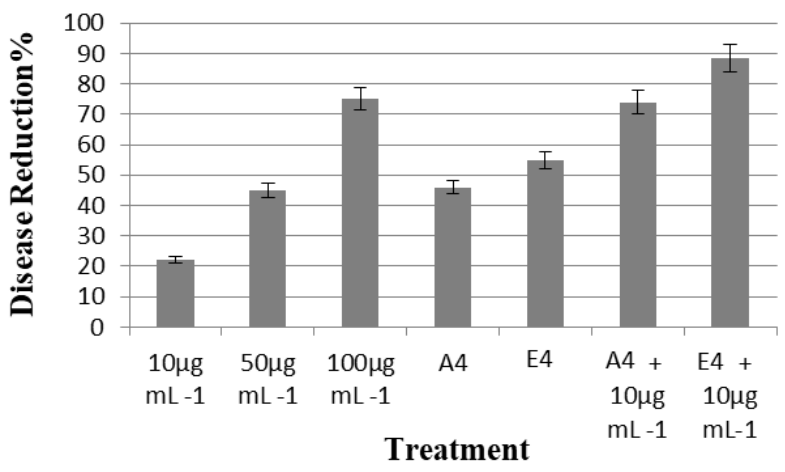

Fig. 3. Efficacy of B4 and E4 or carbendazim alone (10-100 g $\left.\mathrm{mL}^{-1}\right)$ and carbendazim $\left(10 \mu \mathrm{gmL}^{-1}\right)$ combined with the bacterial agents against Fusarium root rot. 
with carbendazim, also provided a similar reduction in symptom development (Fig. 3). The efficacy of Bacillus Licheniformis B4 and Enterobacter E4 or carbendazim alone $\left(10-100 \mathrm{~g} \mathrm{~mL}^{-1}\right)$ and carbendazim $\left(10 \mu \mathrm{gmL}^{-1}\right)$ combined with the bacterial agents against Fusarium root rot expressed as the percentage reduction in visible symptom expression. Errors bars are the standard error of the mean of three repeated experiments comprising 25 plants per treatment.

The use in vivo rather than in vitro screening is often considered the most desirable first step in the testing and selection of potential biocontrol agents. In vitro techniques may be employed later to help identify the mechanisms involved in the biocontrol process [18]. However, in this study the in vitro screening procedure was also used in the primary screening of the bacteria. This allowed for a rapid screening of large numbers of potential antagonists. Selection of bacterial agents by an in vitro technique is therefore an appropriate primary screen, as antibiotic production is readily detectable on agar media.

The successful candidate microorganisms selected in primary screening were further tested at higher pathogen inoculum levels. Quantifying the amount of inoculum added to the seedling compost is an important prerequisite for biological control screening. The biology of the pathogen and this distribution level in the soil levels have significant effects on the disease pressure exerted and the occurrence of significant crop damage [10]. The inoculum concentration was therefore increased in order to exert more stringency in the selection of promising antagonists. In the final screening, two bacterial isolates emerged as potential biocontrol agents. The bacterial isolates, in particular, were found to have the potential to give a highly significant reduction in disease symptoms, to less than $20 \%$ of that observed in pathogen-inoculated controls. The most effective bacterial isolates were identified as Bacillus Licheniformis B4 and Enterobacter E4. Ganney et al. (2016) have shown that these particular species can provide good protection against certain soilborne pathogens [19]. The protection achieved by this biocontrol agent was as effective as seed treatment with metalaxyl - at all temperatures tested [20].

Although the isolate of Fusarium used in this research proved to be sensitive to carbendazim, there are many reports of the use of $\mathrm{MBC}$ fungicides in the control of Fusarium diseases. For instance, [20] reported that carbendazim proved most effective in reducing or delaying the appearance of Fusarium wilt symptoms of cyclamen when the dosage was applied in two applications.

There are, however, many instances in which crop protection provided by $\mathrm{MBC}$ fungicides has failed because of the presence of resistant strains of fungal pathogens, including, for example, Fusarium root rot of young olive trees ( $F$. oxysporum and solani) [14]. Incompatibility between chemical pesticides and microbial antagonists may be a problem in the combined use of chemical and biocontrol agents for integrated control strategies. The results of this study show that both isolates tested displayed high levels of tolerance to the fungicide used. Compatibility between bacterial agents and fungicides has been reported by several researchers; an alternative approach to integrated control root rot of olive was reported by [20], who described promising disease control using a combination of the biocontrol agent of induced plant resistance.

Integration of fungicides with the biocontrol agents tested offers the opportunity to reduce the amounts of fungicides applied as inert substrates; carbendazim is applied to roots, through in crops grown in soil or peat bags it is applied as a drench at $250 \mu \mathrm{g} \mathrm{mL}$. Investigating the efficacy of the selected antagonists integrated with a reduced fungicide application in growing compost indicated that, even at very low concentrations, the combination treatments were able to reduce plant disease significantly. The combination of isolate B4 with $100 \mu \mathrm{g} \mathrm{mL} \mathrm{m}^{-1}$ carbendazim was able to suppress the disease to below $20 \%$ of that obtained when $10 \mu \mathrm{g} \mathrm{mL} \mathrm{m}^{-1}$ of the fungicide was used alone. Although good disease control was provided by $250 \mu \mathrm{g} \mathrm{mL} \mathrm{mL}^{-1}$ carbendazim alone, the risk of fungicide resistance would be a potential problem. The combination of a biological control agent with a fungicide could both reduce the risk of the occurrence of fungicide resistance and improve the reliability of disease control compared with that provided using a bacteria alone. Such treatments that provide promising levels of control require evaluation under commercial growing conditions and over an extended growing period. It should be noted, however, that the disease control provided by the bacteria used in the combination experiments was equally effective when they were applied alone. Nevertheless, an integrated strategy may provide more stable disease control under conditions, where biological control agents may not function well, such as at low temperatures or where there is a history of fungicide groups failing as a result of the emergence of resistant strains. Such a versatile approach may also lead to reduced fungicide application rates, with associated benefits to residue levels in food and to environmental contamination.

\section{Conclusions}

In this paper, we developed a new strategy for the control of Fusarium root rot of olive, indicating that control with an isolate of Enterobacter Cocalae and Bacillus Licheniformis bacterial agents originally isolated in a rhizosphere are feasible for reducing disease by $\geq 40$. The two most efficacious bacterial isolates reduce disease by $46 \%$ for Bacillus B4 and by $51 \%$ for Enterobacter E4, and that combination with carbendazim-based fungicides could provide an alternative disease control. The combination of

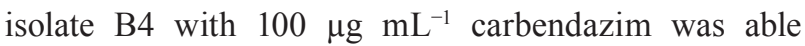


to suppress the disease to below $20 \%$ of that obtained when $10 \mu \mathrm{g} \mathrm{mL}^{-1}$ of the fungicide was used alone (although good disease control was provided by $250 \mu \mathrm{g} \mathrm{mL}^{-1}$ carbendazim alone). The combination of a biological control agent with a fungicide could both reduce the risk of the occurrence of fungicide resistance and improve the reliability of disease control compared with that provided using a bacteria alone.

Finally, these findings push new interest in the biological control agents that should be further investigated as an alternative measure for reducing the risk associated with the use of synthetic pesticides.

\section{Acknowledgements}

The authors are grateful to the Ministry of Higher Education and Scientific Research, Tunisia for a predoctoral grant to Amira Bouzoumita. Thanks are also due to the Institute of the Arid Regions Medenine in Tunisia for their support and to the Spanish National Research Council for microorganism bacteria and fungi identification.

\section{Conflict of Interest}

The authors declare no conflict of interest.

\section{References}

1. SAKARE, UNVER H., BAKIRR M., ULAS M., SAKAR Z.M., Genetic Relationships Among Olive (Olea europea L.) Cultivars Native to Turkey. Biochemical Issue 4, 348, 2015.

2. BOUZOUMITA A., RHOUMA A., BELHOUCHETTE K. FERCHICHI A. Etude de la sensibilité variétale de quelques plans d'olivier du sud Tunisien vis-à-vis la maladie de dépérissement causé par des champignons telluriques .Journal of new sciences, Agriculture and Biotechnology, 27 (9), 1519, 2016.

3. HIBAR K., GAMAOUN W., TRIKI M.A.. Isolation, identification and biological control of the major pathogens causing root rot and wilt diseases of young olive trees in Tunisia. Journal of new sciences, Agriculture and Biotechnology, 39 (4), 2121, 2017.

4. El-MOUSA M.S., ALI M.K., MOUSA A.A., ELEWA I.S. Root rots disease of olive transplants and its biological control. Arab Universities Journal of Agricultural Sciences, 14, 395, 2006.

5. El-MORSI M.E.A., HASSAN M.A.E., ABO-REhAB M.E.A., RADWAN F.M. Incidence of root-rot and wilt disease complex of olive trees in New Valley Governorate in Egypt and its control. Assiut J. Agric. Sci. 40, 105, 2009.

6. SANEI S.J., RAZAVI S.E. Survey of Olive Fungal Disease in North of Iran. Annual Review \& Research in Biology, 2, 27, 2012.
7. TELlO-MARQUINA J.C., ALABOUVETTEC Observations sur la persistance dans le sol des microconidies de Fusarium oxysporum. Agronomie, EDP Sciences, 4 (9), $885,1984$.

8. NASRAOUI B. Les champignons et pseudo-champignons pathogènes des plantes cultivées. Biologie, Nouvelle Systématique, 2011.

9. KAMBLE S.M., ROKDE A.U., CHAVAN A.M. Antifungal activity of algal extracts against plant pathogenic fungi. International Multidisciplinary Research Journal, 2, 23, 2012.

10. BOUGHALLEB-M'HAMDI N., SOULI M., BEN SALEM I., SELMI S., ROMDHANI M.E. Screening of fungi implicated in the dieback of olive trees (Olea europea) in Chebika's area Research in Pla nt Biology, 1, 33, 2011.

11. SIVASAKTHI S. USHARANI, SARNAJ P. Biocontol potentiality of plant growth promoting bacteria (PGPR) pseudomonas fluorescence and bacillus subtilis review. Afric journal of agricultural research 1255, 2014.

12. KAMBLE S.M., ROKDET A.U., CHAVAN A.M. Antifungal activity of algal extracts against plant pathogenic fungi. International Multidisciplinary Research Journal, 2, 23, 2012.

13. ABDEL-MONAIM M.F., EL-MORSI M.E.A., HASSAN M.A.E. Control of root rot and wilt disease complex References of some evergreen fruit transplants by using plant growth promoting rhizobacteria in the New Valley Governorate, Egypt. Journal of Phytopathology and Pest Management 1, 23, 2014.

14. O'NEILL T.M. Evaluation of fungicides against fusarium wilt (Fusarium oxysporum f.sp. cyclaminis) of cyclamen. Tests of Agrochemicals and Cultivars, 16 Annals of Applied Biology 126 (Suppl.), 20, 1995.

15. KAMMOUN G.L., GARGOURI S., HAJLAOUI M.R., MARRAKCHI M. Occurrence and distribution of Microdochium and Fusarium species isolated from durum wheat in northern Tunisia and detection of mycotoxins in naturally infested grain. Journal of Phytopathology, 157, 546, 2009.

16. RUANO-ROSA D., MERCADO-BLANCO J. Springer International Publishing Switzerland 2015 M.K. Meghvansi, A. Varma (eds.), Organic Amendments and Soil Suppressiveness in Plant Disease Management, Soil Biology 46, 2015.

17. KRID S., TRIKI M.A., GARGOURI A., RHOUMA A. Biocontrol of olive knot disease by Bacillus subtilis isolated from olive leaves. Ann. Microbiol. 2011.

18. BACON C.W., HINTON D.M. Endophytic and Biological Control Potential of Bacillus mojavensis and Related Species. Biological Control 23, 274, 2002.

19. GHANNET N., LOCANTARE P., NAHDI S., FERCHICHI A., IACOBELLIS N.S. Potential Biocontrol Effect of the Phylloplane Bacterium Bacillus mojavensis A-BC-7 on the Olive Knot Disease. J Plant Pathol Microbiol 7, 337, 2016.

20. BENHAMOU N. Integrated biological control of tomato crown and root rot by combination of chitosan with endophytic bacteria. Integrated Control in Glasshouses, IOBC Bulletin 22, 5, 1999. 